\title{
КОНДЕНСАЦІЯ ЕКСИТОНІВ У КВАНТОВИХ ЯМАХ. САМООРГАНІЗАЦІЯ ПРОТИ БОЗЕ-КОНДЕНСАЦІЇ
}

\author{
В.Й. СУГАКОВ
}

УдК 535.37, 538.958

(C) 2011

Інститут ядерних досліджень НАН України

(Просп. Науки, 47, Київ 03680)

\begin{abstract}
Проведено аналіз інтерпретації експериментальних даних по спектрах випромінювання екситонів з подвійних квантових ям. Особливості у просторовому розподілі випромінювання та в його поведінці залежно від температури та інтенсивності накачки пояснюються з точки зору існування конденсовної фази екситонів, зумовленої взаємодією між екситонами, а не їх бозеейнштейнівською конденсацією. Структура просторового розподілу густини екситонів у конденсованій фазі залежить від часу життя екситонів і є наслідком процесів самоорганізації в нерівноважних системах. Залежно від накачки досліджено розподіл екситонів по делокалізованих та локалізованих станах i його вплив на спектри випромінювання. Знайдено рівняння гідродинаміки екситонів, яке враховує взаємодію між екситонами. Показано існування екситонних солітоноподібних станів (автосолітонів) за межами області спінодального розпаду.
\end{abstract}

\section{1. Вступ}

При пошуках бозе-ейнштейнівської конденсації екситонів у подвійних квантових ямах була виявлена низка нетривіальних ефектів. Характерною особливістю екситонів у подвійних квантових ямах при електричному полі, спрямованому паралельно нормалі до ям, є надзвичайно великий час життя [1]. Ефект зумовлений розділенням електронів і дірок по різних ямах, що приводить до слабкого перекривання їх хвильових функцій і гальмування процесів взаємної рекомбінації. Великий час життя дозволяе при невеликих накачках створити високу концентрацію екситонів i досліджувати прояв їх взаємодії. Екситони з локалізованими електронами і дірками в різних ямах у літературі називають "непрямими". Наявність дипольного моменту у непрямих екситонах повинна приводити до їх взаємного відштовхування і ускладнення в утворенні конденсованої фази екситонів. Всі ці факти з урахуванням того, що екситони мають цілий спін і малу ефективну масу сприяють утворенню бозе-ейнштейнівської конденсованої фази екситонів у подвійних квантових ямах і стимулюють пошуки цієї фази. Дослідження привели до низки нових результатів. У спектрах випромінювання непрямих екситонів
3 подвійної квантової ями на базі AlGaAs в екситонній області спектра було виявлено і досліджено вузьку смугу, що мала незвичні властивості [2-4]. Смуга з'являється при певній пороговій накачці. Температурна залежність інтенсивності випромінювання при фіксованій накачці описується прямою лінією, що перетинає вісь абсцис при значеннях температури, при якій інтенсивність випромінювання дорівнюе нулю, тобто при температурі, яка для накачки, що розглядається, є пороговою. За фіксованої температури при невисоких накачках залежність випромінювання від накачки є надлінійною. Автори [3, 4] побудували фазову діаграму порогова накачка-температура. Фазова діаграма має особливості: залежність порогової накачки від температури не прямує до нуля при $T \rightarrow 0$.

Нетривіальними виявились результати стосовно просторового розподілу випромінювання екситонів 3 квантової ями. У роботах $[5,6]$ спостерігалась поява кільця у спектрах випромінювання з подвійної квантової ями за межами лазерної плями, в якій збуджуються екситони. Радіус кільця набагато перевищував довжину дифузійного зміщення екситонів. Пояснення появи кільця наведено в роботах $[7,8]$ при припущенні, що дірки більш ефективно порівняно з електронами захоплюються квантовою ямою, i, крім того, у кристалі існують донори, які створюють деяку концентрацію вільних електронів. Тому в квантовій ямі виникає область в околі лазерної плями збагачена дірками, за межами цієї області квантова яма збагачена вільними електронами. На межі області відбуваються процеси рекомбінації, які приводить до утворення екситонів на кільці і просторового розподілу випромінювання у вигляді кільця.

Інтригуючим фактом у властивостях непрямих екситонів $є$ виявлення різноманітних просторових неоднорідних структур у спектрах випромінювання при накачках більших за порогове значення. Так, в роботі [5] спостерігалось розбиття кільця випромінювання на окремі фрагменти, періодично розміщені вздовж кільця. У роботі [9], в якій збудження квантової ями проводилось через вікно в металевому еле- 
ктроді, в спектрах люмінесценції з квантової ями автори спостерігали періодичну структуру у вигляді острівців, розміщених вздовж кільця під периметром вікна. Кількість острівців зростала зі збільшенням радіуса вікна. Непрямі екситони можуть бути створені не тільки в подвійних квантових ямах, а також в широкій квантовій ямі в сильному електричному полі. Електричне поле розподіляє електрони і дірки по різних боках квантової ями, створюються екситони 3 сильно рознесеними у просторі зарядами, i, як наслідок, з великим часом життя [10]. На таких дипольних екситонах у роботі [11] спостерігались ефекти аналогічні ефектам на екситонах у подвійних квантових ямах. Нещодавно Тімофєєв 3 співавторами [12] навели приклади структур у спектрах випромінювання для різних форм вікон в електроді: прямокутника, двох кругів тощо. У роботі [13] автори, підбираючи форму електродів, створили додатковий періодичний потенціал для екситонів. Виявилось що, крім утворення періодичної структури, нав'язаної зовнішніми умовами, спостерігається розбиття випромінювання на періодично розміщені фрагменти в напрямку, перпендикулярному до напрямку з періодичним потенціалом, тобто в напрямку, в якому система є майже однорідною.

Явище втрати симетрії і утворення структур у спектрах випромінювання непрямих екситонів стимулювало теоретичні дослідження з метою пояснення явища [14-19]. Автори роботи [14] розглянули нестійкість, яка виникає при кінетиці заселення рівнів частинками зі статистикою Бозе-Ейнштейна, а саме, збільшення заселеності рівня з нульовим імпульсом буде стимулювати переходи екситонів на цей рівень. Проте необхідні для пояснення густини екситонів виявилися вищі, а температури нижчі, за спостережувані на досліді. Деякі автори пояснюють періодичність Бозе конденсацією екситонів $[15,16]$. Пропонується описувати систему нелінійним рівнянням Шредінгера [17]. Також описується можливість переходу Мотта в системі [18]. У роботах зусилля спрямовані на принципіальну можливість утворення періодичності без конкретного застосування для пояснення інших властивостей спостережуваних систем (залежності від накачування, температури та інших).

Інший підхід до пояснення експериментів по дослідженню екситонів у подвійних квантових ямах розвинуто в роботах [20-24, 28]. Підхід грунтується на таких припущеннях.

1. Існує конденсована фаза непрямих екситонів, зумовлена взаємодією між екситонами. Як вже зазначалось, між непрямими екситонами діють сили диполь-дипольного відштовхування. Проте нескладні розрахунки показують, що при невеликих відстанях між ямами, коли дипольний момент екситонів не $\epsilon$ занадто великим, притягувальні обмінна і ван-дерваальсівська взаємодії можуть перевищувати дипольдипольне відштовхування на певних відстанях між екситонами. Існування притягувальної взаємодії підтверджується при розрахунках біекситонів [25-27], а також дослідженнями багатоекситонної системи [29].

2. Важливу роль у формуванні розподілу екситонних фаз у просторі відіграє скінченний час життя екситонів. Як правило, час життя екситонів набагато перевищує час встановлення локальної рівноваги. Тому в багатьох задачах час життя екситонів вважається нескінченним. Проте при дослідженні просторового розподілу фаз у двофазних системах врахування скінченності часу життя є необхідним, оскільки час життя є меншим за час встановлення рівноваги між фазами. Останній час визначається повільними дифузійними процесами і є великим. Саме скінченний час життя екситонів обмежує максимальний розмір конденсованої фази і приводить до існування кореляції в положенні окремих областей конденсованих фаз. Таким чином, утворювані просторові структури нерівноважні і є наслідком процесів самоорганізації в нерівноважних системах. Саме при підході з точки зору процесів самоорганізації в роботі [30] було показано появу нестабільності при великій густині екситонів з притягувальною взаємодією і утворення періодичного розподілу густини.

Теорія, розвинена в роботах [20-24, 28], пояснила майже всі особливості прояву непрямих екситонів. Так, спостережувану в [4] поведінку вузької лінії залежно від накачки і температури наведено в [21], поясненню просторової структури розподілу екситонної густини, виявленої в роботах $[5,9]$, та її динаміки при зміні накачки та температури присвячено роботи [20-24]. Експериментальну фазову діаграму "порогова накачка-температура" [3,5] пояснено в [21]. При побудові теорії було використано два підходи в теорії фазових переходів: зародження-росту (ЛіфшицаСльозова) та спінодального розпаду (Кана-Хілерта), узагальнивши їх на частинки зі скінченним часом життя, що є важливою обставиною для інтерпретації експериментальних результатів. При цьому залучення статистики Бозе-Ейнштейна для екситонів не є обов'язковим, конденсація, що розглядається, не є конденсацією Бозе-Ейнштейна. Теорія пояснює всі спостережувані результати за винятком двох, наведе- 
них нижче, які в межах запропонованої теорії ще не розглядали.

1. У роботі [31] було експериментально показано, що максимум частотної залежності випромінювання фотонів з області між острівцями нижчий, ніж максимум частоти випромінювання з області, в якій густина екситонів максимальна, тобто з острівців. Різниця частот є малою, меншою, ніж ширина смуги випромінювання. Проте на підставі цих даних автори прийшли до висновку, що між екситонами відбувається відштовхувальна взаємодія. Цей результат суперечить основному припущенню моделі робіт [20-24, 30] про наявність притягання між екситонами і утворення конденсованої фази.

2. У роботах $[12,32,33]$ спостерігали когерентність у спектрах випромінювання від різних областей острівка конденсованої фази [33] або навіть від окремих острівців $[12,32]$. Когерентність проявлялась у спостереженні інтерференції випромінювання від різних просторових точок.

Ефект 2 у даній роботі не розглядається. Проте можна дати для нього таке якісне пояснення. На експерименті безпосередньо спостерігається не інтерференція хвильових функцій, а інтерференція електромагнітних хвиль, випромінених системою. Інтерференція випромінювання від двох острівців може виникнути внаслідок накладання електромагнітного поля, випроміненого одним острівцем і розсіяним значенням цього ж поля іншим острівцем, оскільки електромагнітна хвиля і розсіяна хвиля є когерентними. У роботах [34-36] показано, що при існуванні конденсованої фази має місце сильна кореляція екситонної густини в різних точках простору, що приводить до взаємозв'язку випроміненої хвилі в деякій області з розсіяною хвилею іншою областю. Також існує різкий максимум фур'є-перетворення кореляційної функції як функції хвильового вектора. Проте для кількісних розрахунків інтерференції в такій моделі невистачає даних про мікроскопічну модель конденсованої фази екситонів, зокрема кількісних даних про її поляризованість.

Пояснення ефекту 1 викладено в наступному параграфi.

\section{2. Розподіл екситонів по локалізованих та делокалізованих станах}

Як вже зазначалось, в системі острівців, що спостерігаються [5] на кільці за межами лазерної плями, згідно з [31] частота випромінювання з області з більшою концентрацією екситонів (з острівців) вища, ніж з області з нижчою концентрацією. Це привело авторів [31] до висновку, що екситони відштовхуються і, отже, утворення конденсованої фази, зумовлене притяганням між екситонами, неможливе. Це суперечить основному припущенню робіт [20-24], в яких пояснюються численні експерименти. Усунемо цю суперечність, врахувавши наявність рівнів локалізованих екситонів. Причинами утворення локалізованих станів можуть бути наявність залишкових донорів, акцепторів, дефектів, які створюють випадковий флуктуаційний потенціал для екситонів. На даний час пояснення утворення локалізованих станів для конкретних випадків однозначно не встановлено, проте їх існування підтверджується наявністю випромінювання в області частот менших частоти випромінювання екситонної зони. При низьких температурах і низьких накачках основна доля випромінювання, що формує смугу, складається з випромінювання з домішкових центрів. Згідно з роботами $[4,5]$ ширина смуги випромінення в околі дна зони непрямих екситонів в подвійних квантових ямах на базі AlGaAs має порядок 1,5-2 меВ. Вузька смуга шириною порядку 0,2-0,3 меВ, яка пов'язується з конденсованою фазою екситонів, з'являється при зростанні накачки на фіолетовому крилі спектра [4]. У роботах Бутова та інших [5] ця вузька смуга не спостерігається, спектри випромінювання екситонів і локалізованих станів не розділяються, тому досліджується форма спільної смуги, в яку дають внесок як конденсована фаза, так і локалізовані дефекти. Дослідимо співвідношення між внеском у смугу випромінювання вільних екситонів і екситонів, локалізованих на дефектах.

Екситонні стани (вільні і локалізовані) заселяються після утворення електронів і дірок зовнішнім опроміненням та їх подальшої релаксації і рекомбінації. Зазвичай, час релаксації набагато менший за час життя екситонів. Тому можна вважати, що екситони знаходяться у стані квазітермодинамічної рівноваги. Проте для глибоких локалізованих станів при низьких температурах така рівновага може не встановлюватись, оскільки процеси з переходами з нижніх рівнів на верхні є малоімовірними. Тому ми будемо припускати, що вільні екситони знаходяться в стані квазітермодинамічної рівноваги, а розподіл екситонів, локалізованих на пастках, будемо знаходити з кінетичних рівнянь. Розглянемо розподіл екситонів по вільних і локалізованих станах в умовах стаціонарного опромінення. При розрахунках будемо вважати, що: 1) домішкові центри можуть захоплювати по одному екситону, 2) температура є настільки низькою, що область заселення екситонної зони (величина $\kappa T$ ) 


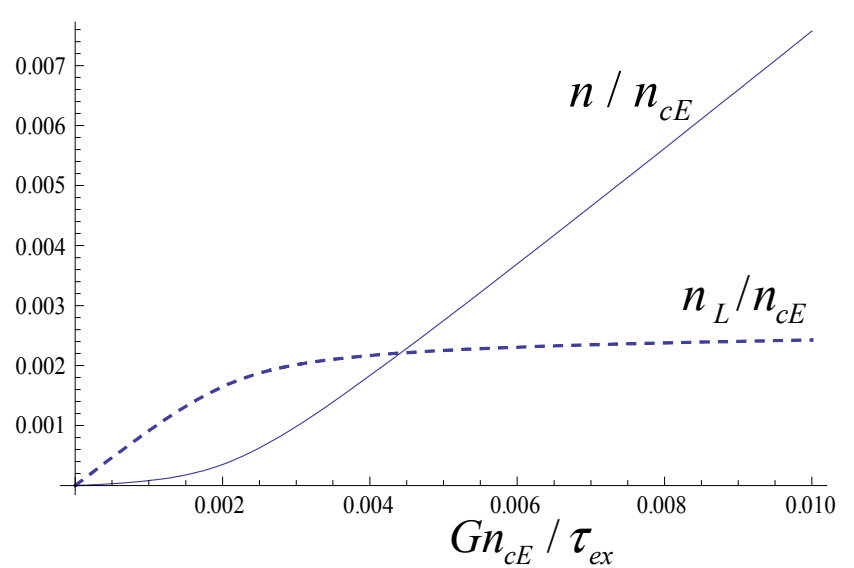

Рис. 1. Залежність густини вільних (суцільна крива) та локалізованих (пунктирна крива) екситонів від накачки. Параметри системи: $T=2 \mathrm{~K}, N_{l}=0,0032 n_{c E}, W_{\mathrm{ex}, l} \tau_{\mathrm{ex}} n_{c E}=10000$; $\alpha=300(\mathrm{eB})^{-1}$

набагато менша від ширини смуги, яка формується як делокалізованими екситонами, так і дефектними станами; тоді екситонну систему можна описати густиною вільних екситонів $n$-числом екситонів на одиницю площі квантової ями. Будемо описувати систему густиною локалізованих екситонів, віднесеної до одиничного інтервалу енергії, $-n_{l}(E)$. Енергетичний розподіл домішкових рівнів описуватимемо функцією $\rho(E)$, яка визначає число рівнів в одиниці поверхні в одиничному інтервалі енергії. Домішкові рівні заселяються внаслідок переходів збуджень з екситонних станів на домішкові. Можливі також зворотні переходи від домішкових рівнів в екситонну зону. При малих концентраціях пасток перенесенням збуджень між пастками можна нехтувати. Система кінетичних рівнянь для заселеностей рівнів має вигляд

$$
\begin{aligned}
& \frac{d n}{d t}=G-\frac{n}{\tau_{\mathrm{ex}}}-\int W_{\mathrm{ex}, l}(E) n\left(\rho(E)-n_{l}(E)\right) d E \\
& +\int W_{l, \mathrm{ex}}(E) n_{l}(E) n_{c E} d E
\end{aligned}
$$

$\frac{d n_{l}(E)}{d t}=-\frac{n_{l}(E)}{\tau_{l}(E)}+W_{\mathrm{ex}, l}(E) n\left(\rho(E)-n_{l}(E)\right)-$

$-W_{l, \mathrm{ex}}(E) n_{l}(E) n_{c E}$,

де $\tau_{\text {ex }}$ i $\tau_{l}(E)$ - часи життя вільного і локалізованного на пастці екситона відповідно, $G$ - число екситонів, створених за одиницю часу на одиниці площини квантової ями, $W_{\text {ex }, l}(E)$ і $W_{l, \text { ex }}(E)$ - імовірності прямого і зворотного переходів екситона за одиницю часу з екситонної зони на пастку з енергією $E$ при одному екситоні на одиницю поверхні. Множник $\left(\rho(E)-n_{l}(E)\right)$ у формулі $(1)$ враховує той факт, що переходи можливі на вільні стани пасток. Останній член у формулі (1) описує переходи з пасток в екситонну зону. Імовірність такого переходу пропорційна імовірності переходу для одного екситона, заселеності пасток та густині екситонів у пастці $n_{c E}$. При одному екситоні на пастці остання величина обернено пропорційна поверхні, що займає пастка.

Розглянемо енергетичний розподіл збуджень при стаціонарному опроміненні. Для цього величину $n_{l}(E)$, знайдену з рівняння $(2)$, підставимо в рівняння (1). У результаті дістанемо рівняння для визначення екситонної густини

$n_{L}+n=G \tau_{\mathrm{ex}}$

де $n_{L}$ - повне число екситонів, локалізованих на пастках:

$n_{L}=n \tau_{\mathrm{ex}} \int_{-\infty}^{0} \frac{W_{\mathrm{ex}, l} \rho(E) d E}{W_{\mathrm{ex}, l}\left(n+n_{c E} \exp (E / \kappa T)\right) \tau_{l}(E)+1}$.

У формулі ми врахували зв'язок між прямими та зворотними переходами: $W_{l, \mathrm{ex}}=W_{\mathrm{ex}, l} \exp (E / \kappa T)$, де енергія домішкового рівня $E$ відраховується від дна екситонної зони $(E<0)$. Подальші розрахунки вимагають інформацію про конкретні значення коефіцієнтів у рівнянні (3). Для отримання якісної картини розподілу збуджень розглянемо таку модель. Залежність густини енергетичного спектра від енергії має експоненційний характер, тобто $\rho(E)=\alpha N_{l} \exp (\alpha E)$, де $N_{l}$ - густина домішкових центрів, матричний елемент переходу з екситонного стану на дефект $W_{\text {ex }, l}$ не залежить від $E$, часи життя в кожному стані є однаковими $\tau_{\text {ex }}=\tau_{l}$. Результати розрахунків екситонної густини і густини заселених пасток для певних параметрів наведено на рис. 1.

При лінійних розмірах пастки $10^{-6}$ см, параметр $n_{c E}$ має порядок $10^{12} \mathrm{~cm}^{-2}$. Концентрація дефектів при параметрах, вибраних для розрахунку, див. рис. 1 , дорівнює $3,2 \cdot 10^{9} \mathrm{~cm}^{-2}$. Ширина смуги, створена пастками, має порядок 0,003 еВ. При малих накачках смуга випромінювання формується випромінюванням збуджень з пасток. При великих накачках заселення пасток насичується, згідно з рис. 1 при насиченні концентрація збуджень є величиною порядку $2 \cdot 10^{9} \mathrm{~cm}^{-2}$, при цьому екситони при притягувальній взаємодії утворюють конденсовану фазу. Енергія 
в конденсованій фазі на один екситон зменшується у порівнянні з енергією вільних екситонів (жирна лінія на рис. 2).

Тому екситонам енергетично вигідно утворити конденсовану фазу, проте ця зміна енергії (величина приблизно 0,0002 eB) є меншою за ширину смуги. Проте, оскільки в області острівців густина екситонів більша за густину збуджених станів пасток, а їх енергія випромінювання вища за енергію випромінювання пасток, максимум випромінювання з острівців зміщуеться в короткохвильову область. Перейти з області конденсованого стану (з острівців) на пастки (тобто в стани з нижчою енергією) екситони не можуть, оскільки рівні пасток заселені. Таким чином, частота випромінювання з області конденсованого стану більша, ніж з області газового стану навіть при притягувальній взаємодї між екситонами.

Відзначимо, що в роботі [5] смуга випромінювання 3 конденсованої фази ширша, ніж смуга, що спостерігалась в роботі [4] при іншому методі створення екситонів. Можливо, це пов'язано з фактом, що в дослідженнях [5] екситони утворюються в області $p-n$-переходу: з одного боку до області підходять електрони, а з іншого - дірки. Екситони знаходяться у просторі, між областями, збагаченими з одного боку електронами, а з іншої - дірками. Щоб з'єднатись в екситони електрони і дірки повинні обов'язково проходити область конденсованої фази, тому ця область насичена зарядами, які створюють електричні поля і приводять до розширення смуг.

\section{3. Гідродинаміка екситонів в конденсованій фазі}

Гідродинамічні рівняння для екситонів отримано та проаналізовано в роботі [37]. Ми отримаємо рівняння гідродинаміки для екситонів у конденсованій фазі, узагальнюючи рівняння Навье-Стокса. Система характеризується густиною екситонів $n \equiv n(\mathbf{r}, t)$ та швидкістю руху екситонної рідини $\mathbf{u} \equiv \mathbf{u}(\mathbf{r}, t)$. Рівняння неперервності для екситонів переписуємо так:

$$
\frac{\partial n}{\partial t}+\operatorname{div}(n \mathbf{u})=G-\frac{n}{\tau_{\mathrm{ex}}}
$$

Таким чином, в порівнянні $з$ типовим рівнянням неперервності для рідини в рівняння для екситонів додано члени, що описують накачування та скінчений час життя екситонів.

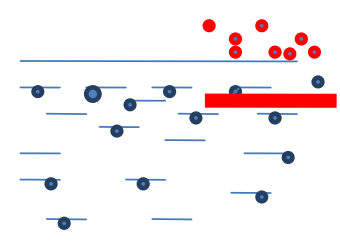

a

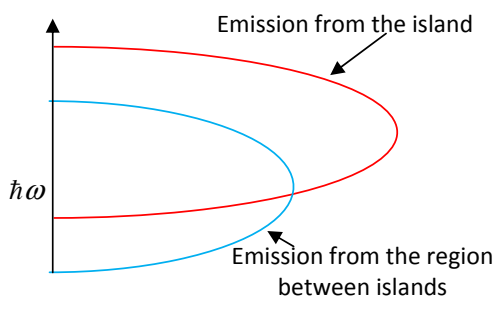

b
Рис. 2. Збудження по пастках та по станах екситонної зони. Жирна лінія на рис. $2, a$ відповідає енергії на один екситон в конденсованій фазі. На рис. $2, b$ верхня крива описує форму смуги випромінювання з острівця (екситонів і пасток), нижня - смугу випромінювання пасток

Рівняння руху одиниці об'єму для екситонної рідини переписуємо у вигляді

$\frac{\partial m n u_{i}}{\partial t}=-\frac{\partial \Pi_{i k}}{\partial x_{k}}-\frac{m n u_{i}}{\tau_{s c}}$

де $m$ - маса екситона, $\Pi_{i k}-$ тензор густини потоку імпульсу:

$\Pi_{i k}=P_{i k}+m n u_{i} u_{k}-\sigma_{i k}^{\prime}$,

де $P_{i k}$ - тензор тиску, $\sigma_{i k}^{\prime}$ - в'язкий тензор напружень.

$\mathrm{У}$ порівнянні з типовим рівнянням Навьє-Стокса в рівняння (6) введено гальмування екситонної рідини на дефектах та фононах за допомогою часу розсіяння $\tau_{s c}$. У рівнянні (6) ми знехтували зміною імпульсу, зумовленого народженням та зникненням екситонів. Так, зміна імпульсу системи за одиницю часу в одиниці об'єму внаслідок зникнення екситонів має порядок $m n u / \tau_{\text {ex }}$. Оскільки $\tau_{\text {ex }} \gg \tau_{s c}$, ця величина набагато менша за останній член у формулі (6). Також малою є зміна імпульсу, зумовлена введенням нових екситонів у систему.

Вводячи коефіцієнти в'язкості та використовуючи рівняння (5), рівняння (6) можна переписати у вигляді

$\rho\left(\frac{\partial u_{i}}{\partial t}+\left(u_{k} \frac{\partial}{\partial x_{k}}\right) u_{i}\right)=-\frac{\partial P_{i k}}{\partial x_{k}}+\eta \Delta u_{i}+$

$+(\varsigma+\eta / 3)\left(\frac{\partial}{\partial x_{i}}\right) \operatorname{div} \mathbf{u}-\frac{\rho u_{i}}{\tau_{s c}}$.

Розглянемо детальніше тензор тиску. Щоб пов'язати його з іншими параметрами, потрібно використати рівняння стану. Знайдемо цей зв'язок, використавши вільну енергію рівноважного стану, вважаючи, що в системі реалізується локальна рівновага. Подамо функціонал вільної енергії у вигляді

$F=\int d \mathbf{r}\left(\frac{K}{2}(\nabla n)^{2}+f(n)\right)$. 
Перший член у підінтегральному виразі (9) описує енергію неоднорідності.

При даному наведенні вільної енергї тензор тиску визначається за формулою [38]:

$P_{\alpha \beta}=\left(p_{0}-\frac{K}{2}(\nabla n)^{2}-K n \Delta n\right) \delta_{\alpha \beta}+K \frac{\partial n}{\partial x_{\alpha}} \frac{\partial n}{\partial x_{\beta}}$,

де $p_{0}=n f^{\prime}(n)-f(n)-$ рівняння конденсованого стану.

Враховуючи (10), остаточно рівняння (8) перепишемо у вигляді

$$
\begin{aligned}
& \frac{\partial u_{i}}{\partial t}+u_{k} \frac{\partial u_{i}}{\partial x_{k}}+\frac{1}{m} \frac{\partial}{\partial x_{i}}\left(-K \Delta n+\frac{\partial f}{\partial n}\right)+\nu \Delta u_{i}+ \\
& +(\varsigma / m+\nu / 3)\left(\frac{\partial}{\partial x_{i}}\right) \operatorname{div} \mathbf{u}+\frac{u_{i}}{\tau_{s c}}=0 .
\end{aligned}
$$

Рівняння (5) і (11) є рівняннями гідродинаміки для екситонної системи. Рівняння (11) відрізняється від гідродинамічного рівняння, дослідженого в [37], присутністю третього члена, що описує конденсовану фазу. Розглянемо випадок, коли конденсована фаза існує. 3 оцінок, зроблених у роботі [37], випливає, що членами з коефіцієнтами в'язкості можна нехтувати. Тоді для процесів, що повільно змінюються в часі, а також у лінійному наближенні стосовно швидкості з рівняння (11) отримаємо значення швидкості $\mathbf{u}$, після підстановки якого в рівняння ((5) зведемо останнє до вигляду

$$
\frac{\partial n}{\partial t}+\operatorname{div} \mathbf{j}=G-\frac{n}{\tau_{\mathrm{ex}}},
$$

де

$\mathbf{j}=n \mathbf{u}=-\frac{\tau_{s c} n}{m} \boldsymbol{\nabla}\left(-K \Delta n+\frac{\partial f}{\partial n}\right)$,

або $\mathbf{j}=-M \nabla \mu$, де $\mu=\delta F / \delta n-$ хімічний потенціал системи, $M=n D / \kappa T-$ рухливість, $D=\kappa T \tau_{s c} / m-$ коефіцієнт дифузії екситонів.

Таким чином, рівняння для екситонної густини набуває вигляду

$$
\begin{aligned}
& \frac{\partial n}{\partial t}=D \Delta n+\frac{D}{\kappa T}\left(-K n \Delta^{2} n-K \nabla n \cdot \nabla n \Delta n\right)+ \\
& +\frac{D}{\kappa T} \nabla \cdot\left(n \frac{\partial^{2} f}{\partial n^{2}} \nabla n\right)+G-\frac{n}{\tau_{\mathrm{ex}}} .
\end{aligned}
$$

Саме у вигляді (14) в моделі спінодального розпаду досліджено нами просторовий розподіл екситонної густини при екситонній конденсації для різних залежностей $f$ від $n[22,23,34,39,40]$. При певних умовах, накладених на функцію $f$, однорідний розв'язок є нестабільним і в системі виникає просторова структура. Для даної системи нестабільність виникає, якщо в залежності $f(n)$ існує мінімум, що відповідає конденсованій фазі. Приклади таких залежностей були наведені в роботах, цитованих вище. В даній роботі ми проаналізуємо іншу залежність $f(n)$, яка часто використовується в теорії фазових переходів. А саме, проаксимуємо густину вільної енергії у такому вигляді:

$f=\kappa \operatorname{Tn}\left(\ln \left(n / n_{o}\right)-1\right)+a \frac{n^{2}}{2}+b \frac{n^{4}}{4}+c \frac{n^{6}}{6}$,

де $a, b, c$ - константи. Для існування конденсованої фази потрібно, щоб величина $b$ була від'ємною. Екситон-екситонну взаємодію описують три останніх члени, перший член введений для того, щоб описати систему при малих концентраціях екситонів.

Введемо безрозмірні параметри: $\tilde{n}=n / n_{o}$, де $n_{o}=$ $(a / c)^{1 / 4}, \tilde{b}=b /(a c)^{1 / 2}, \tilde{\mathbf{r}}=r / \xi$, де $\xi=(K / a)^{1 / 2}-$ довжина когерентності, $\tilde{t}=t / t_{0}$, де $t_{0}=\frac{\kappa T K}{D n_{o} a^{2}}, D_{1}=\frac{\kappa T}{a n_{o}}$, $\tilde{G}=G t_{0} n_{0}, \tilde{\tau}_{\mathrm{ex}}=\tau / t_{0}$. Тоді рівняння (12) приводиться до вигляду (знак $\sim$ в рівнянні опускаємо):

$\frac{\partial n}{\partial t}=D_{1} \Delta n-n \Delta^{2} n-\nabla(n \nabla \Delta n)+n \Delta n\left(1+3 b n^{2}+5 n^{4}\right)+$

$+(\nabla n)^{2}\left(1+9 b n^{2}+25 n^{4}\right)+G-\frac{n}{\tau_{\mathrm{ex}}}$.

При стаціонарній однорідній накачці рівняння (16) має однорідний стаціонарний розв'язок $n=G \tau_{\mathrm{ex}}$. Традиційним методом, лініанізуючи рівняння (16) стосовно малих відхилень від однорідного розв'язку, отримуємо, що однорідний розв'язок стійкий, якщо густина екситонів менша від певного критичного значення $n_{c}$, яке визначається з розв'язку рівняння

$\left(D_{1} / n_{c}^{2}+1+3 b n_{c}^{2}+5 n_{c}^{4}\right) n_{c}-4 / \tau_{\mathrm{ex}}=0$.

При цьому критичне значення накачки дорівнює $G_{c}=n_{c} \tau_{\text {ex }}$. Хвильове число $k_{c}$ та період гратки $\lambda_{c}$ визначаються зі співвідношення

$k_{c}=2 \pi / \lambda_{c}=1 /\left(n_{c} \tau_{\mathrm{ex}}\right)^{1 / 4}$

$n_{c}$ слабо залежить від $\tau_{\text {ех }}$. Пропорційність періоду гратки до величини $\left.\left(\tau_{\mathrm{ex}}\right)^{1 / 4}\right)$ було показано ще в роботі [30]. При накачках більших за порогове значення 
$\left(G>G_{\mathrm{c} 1}\right)$ в системі утворюється періодичний розподіл екситонної густини. На рис. 3 наведено стаціонарне значення екситонної густини для одновимірної системи $n(\mathbf{r}, t) \equiv n(z, t))$ для трьох значень накачки. Періодичний розв'язок існує в певному інтервалі значень накачки $G_{\mathrm{c} 1}<G<G_{\mathrm{c} 2}$.

Розв'язок отриманий з рівняння (16) при початкових умовах $n(z, 0)=0$ і граничних умовах $n^{\prime}(0, t)=$ $n^{\prime}(L, t)=n^{\prime \prime}(0, t)=n^{\prime \prime}(L, t)=0$, де $L$ - розміри системи. Задачу розв'язували також при різних граничних умовах. Взагалі при великих розмірах системи структура розв'язку на певній відстані від границі системи (період надгратки, їі амплітуда) не залежать від граничних умов. Для даних параметрів періодичний розв'язок існує при $0,0056<G<0,00924$. За межами цієї області розв'язок описує однорідну систему - газову фазу при накачках менших від нижньої границі і конденсовану фазу при накачках більших верхньої границі.

Для доведення основного рівняння (14) важливим є останній член в рівнянні (6), який описує втрату імпульсу екситонів внаслідок розсіяння на фононах i дефектах. Саме цей член приводить до затухання екситонного потоку. 3 точки зору можливості появи явища надплинності ситуація для екситонів є складнішою, ніж для рідкого гелію і атомів лужних металів при наднизьких температурах. Справа в тому, що в останніх системах фонони є внутрішньою складовою спектра системи, взаємодія між фононами є взаємодією між атомами і не приводить до зміни повного імпульсу системи і руху її як цілого. Фонони і дефекти для екситонів є зовнішніми підсистемами, які гальмують рух екситонів. Тому для утворення надплинного стану потрібно, щоб в конденсованому стані істотно зростала величина $\tau_{s c}$. Це можливе для екситонних поляритонів, які слабо взаємодіють з фононами і є експериментальні вказівки на спостереження надплинності [41]. Для непрямих екситонів детальної мікроскопічної теорї конденсованого стану та елементарних збуджень в конденсованому стані немає, і тому не показана можливість усунення дії зовнішніх факторів (фононів, дефектів) на систему. Отже, питання про можливість існування явища надплинності для непрямих екситонів залишається відкритим. Також пояснення появи на експерименті піка в випромінюванні непрямих екситонів після виключення накачки, пояснювальне як стимульоване заселення рівнів, зумовлене бозевським характером спектра екситонів [42], є неоднозначним: пік може з'явитись внаслідок збільшення часу життя екситонів після виключення накачки внаслідок усунення оже-процесів (див.

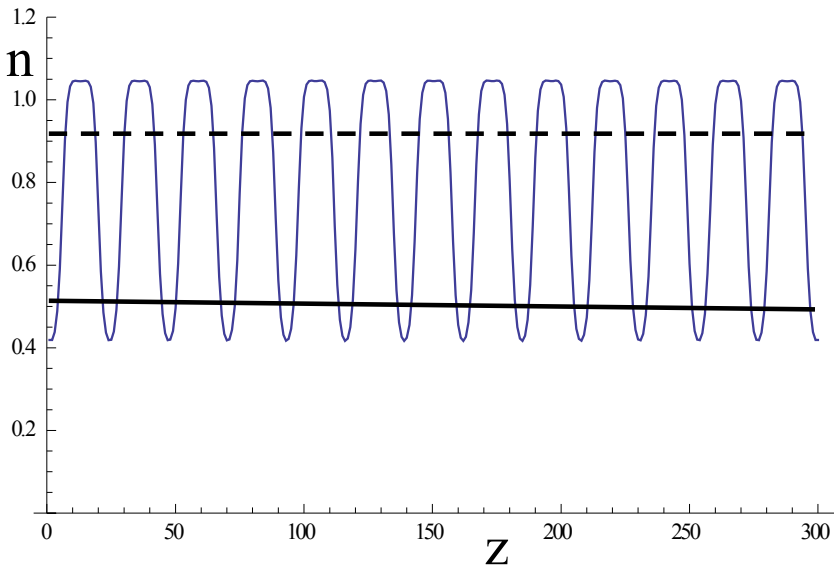

Рис. 3. Просторова залежність екситонної густини для різних значень накачки: суцільна пряма $-G=0,0056$, періодична крива $-G=0,007$, пунктирна пряма $-G=0,00924, D_{1}=0,03$, $b=-1,9$

розрахунки в роботі [21]). Таким чином, особливості, що спостерігаються при великих густинах непрямих екситонах можуть бути пояснені фазовими перетвореннями для частинок, що притягуються, узагальненними на частинки зі скінченним часом життя без залучення бозе-ейнштейнівської конденсації.

\section{4. Екситонні автосолітони}

Як вже зазначалось, при $n<n_{\mathrm{c} 1}\left(G<G_{\mathrm{c} 1}\right)$, однорідний розв'язок рівняння (16) стійкий. Проте виявляється, що в певних межах зміни накачки при $G<G_{\mathrm{c} 1}$ в системі існує локалізований у просторі статичний розв'язок для розподілу екситонної густини. Так, при параметрах, використаних для розрахунку розподілу екситонів на рис. 3, порогове значення накачки дорівнюе $G_{\mathrm{c} 1}=0,0056789$. Проте при стаціонарній накачці існує неоднорідний розв'язок рівняння (16) при $G<G_{\mathrm{c} 1}$ у вигляді усамітненого піка. Його можна отримати, якщо розв'язувати рівняння (16) при накачці, що складається крім сталої величини $G_{0}$ ще 3 додаткового імпульсу $d G$ з максимумом у певній точці простору і в певний моментом часу:

$d G=s \exp \left[-w\left(z-z_{0}\right)^{2}\right] \exp \left[-p\left(t-t_{0}\right)^{2}\right]$

де $s, w, p$ - параметри. Формула (19) описує імпульс накачки, що діє в певному інтервалі часу, з максимумом у просторовій точці $z_{0}$.

Розв'язок рівняння (16), отриманий при накладанні на стаціонарний імпульс додаткового імпульсу (19) при $z_{0}=L / 2$, має вигляд, зображений на рис. 4 . 


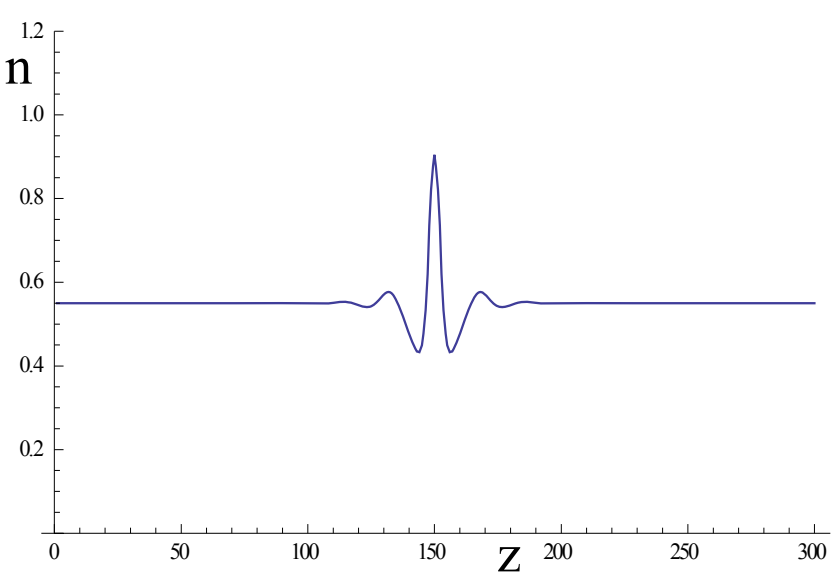

Рис. 4. Просторова залежність екситонної густини при накачці $G=0,0055<G_{\mathrm{c} 1}, D_{1}=0,03, b=-1,9$

Розв'язок існує при $t \rightarrow \infty$, тобто при часах, коли дія додаткового імпульсу вже відсутня. Форма імпульсу $n(z)$ не залежить від параметрів $s, w, p$, за винятком випадків, коли принаймні один із цих параметрів прямує до нуля і стає меншим певного значення. Крім того, розв'язок у вигляді, наведеному на рис. 4 , виникає при $t \rightarrow \infty$, коли додатковий імпульс відсутній, але в початковий момент при $t=0$ існує певний розподіл густини екситонів:

$n(z, 0)=s_{0} \exp \left(-w\left(z-z_{0}\right)^{2}\right)$.

Безпосередніми розрахунками можна переконатись, що розв'язок з локалізованим розподілом густини у вигляді, поданому на рис. 4, є стабільним. Називатимемо стани, що описують ці розв'язки, екситонними автосолітонами, а залежність густини екситонів від координати позначатимемо через $n_{\text {as }}(z)$. Автосолітони існують в певній області накачок $G_{\text {cas }}<$ $G<G_{\mathrm{c} 1}$, менших накачок, необхідних для утворення періодичної структури. Розв'язки існують поряд 3 однорідними розв'язками.

Екситонні автосолітони відповідають усамітненим стаціонарним розв'язкам нелінійного рівняння для екситонів (16). Назва "автосолітон" введена згідно $з$ [43], щоб підкреслити, що усамітнені хвилі у даному випадку виникають в дисипативній системі, тоді як солітони характеризують збудження в консервативній системі. Розв'язки у вигляді автосолітонів є виродженними: якщо існує усамітнений розв'язок $n_{\text {as }}(z)$, то розв'язком у нескінченному середовищі буде функція $n_{\text {as }}\left(z-z_{0}\right)$ при довільному $z_{0}$. Отримані автосолітони є нерухомими збудженнями. Проте, якщо в системі існує зовнішне поле, що створює просторово залежний додатковий потенціал для екситонів, то уса-

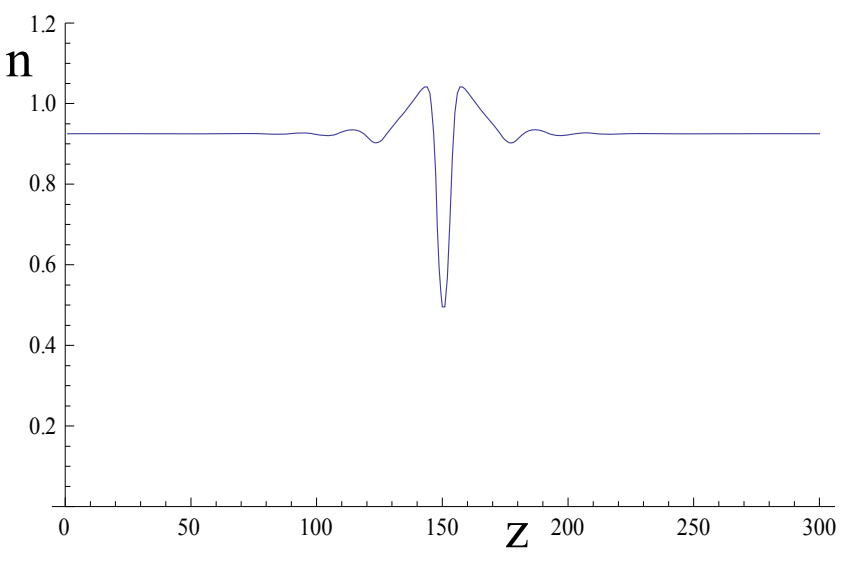

Рис. 5. Просторова залежність екситонної густини при накачці $G=0,0095>G_{\mathrm{C} 2}, D_{1}=0,03, b=-1,9$

мітнені збудження рухаються. Так, при лінійній залежності від координат додаткової потенціальної енергії екситонів у формулу для вільної енергї(15) треба додати член $\delta V=-d z$. Тоді рівняння (16) має розв'язок у вигляді автохвиль $n_{\text {as }}(z-v t)$, де $v$ - швидкість автохвилі. Такі автохвилі для періодичних розв'язків при $G>G_{\mathrm{c} 1}$ розглянуто в роботі [40].

Локалізовані розв'язки існують також у певній області граничних значень накачок, більших за ті, за яких існують періодичні структури. Розв'язки виникають при подачі на систему імпульсу накачки типу (19), але при $s<0$. Приклад такого розв'язку наведено на рис. 5. Проявляються такі структури у вигляді провалу і можуть бути названі екситонними антиавтосолітонами.

Для пояснення утворення автосолітонних розв'язків нагадаємо, що досліджуються фазові перетворення. Як відомо, існує область між спінодаллю та бінодаллю, в якій для появи нової фази потрібне утворення зародка нової фази, розміри якого перевищують певне критичне значення. Знайдені нами критеріі існування однорідного розв'язку при $n<n_{\mathrm{c} 1} 3$ рівняння (17), розглядаючи малі флуктуації, фактично визначають межу спінодалі. Існування неоднорідного розв'язку у вигляді автосолітонів та його виникнення при імпульсах накачки, більших певної величини, відповідає факту виникнення зародків нової фази за межами спінодалі. Проте, оскільки ми досліджуємо нерівноважні процеси і фазові перетворення відбуваються для нестабільних частинок, області спінодалі та бінодалі залежать від часу життя частинок. Крім того, для стабільних частинок радіус нової фази зростає з часом, наприклад, згідно з теорією ЛіфшицаСльозова [44] у тривимірній системі радіус зростає за 
законом $t^{1 / 3}$. У той самий час для частинок зі скінченним часом життя форма розподілу густини частинок для автоекситонів не залежить від часу.

Зауважимо, що в підході до конденсації екситонів у методі народження - росту з узагальненням на нестабільні частинки [20-24] існування острівців за межами спінодалі отримується автоматично, оскільки при ньому враховуються флуктуації, які не наведено в рівнянні (16).

\section{5. Висновки}

У роботі розглянуто деякі питання з теорії конденсації непрямих екситонів у квантових ямах та проведено аналіз експериментів по спектрах непрямих екситонів у квантових ямах на базі AlGaAs.

Зокрема показано, що результати експерименту [31], в якому знайдено, що спектр випромінювання 3 області конденсованої фази зміщений у короткохвильову область у порівнянні з максимумом спектра випромінювання з області газової фази, не суперечать моделі про існування притягувальної взаємодії між екситонами. Під час пояснення враховано, що в спектр випромінювання дають внесок як екситони конденсованої фази, так і дефектні рівні, заселення яких насичується при зростанні накачки.

У моделі спінодального розпаду знайдено розв'язки у вигляді усамітнених станів - екситонних автосолітонів і антиавтосолітонів. Розв'язки відповідають зародкам конденсованої фази в газовій фазі і зародкам газової фази в конденсованій фазі в моделі зародження-росту.

У роботі побудовано рівняння гідродинаміки для екситонів з врахуванням взаємодії між екситонами. Проаналізовано труднощі створення надплинного стану для екситонів внаслідок присутності дефектів і фононів. 3 аналізу, проведенного в роботі, випливає, що нині не існує експериментальних даних, одержаних при дослідженні непрямих екситонів у квантових ямах на базі AlGaAs, які не можна було б пояснити без залучення бозе-ейнштейнівської конденсації екситонів.

Розглянуті в роботі моделі конденсованої фази є феноменологічними. Як було підкреслено нами раніше $[22,23]$, використаний підхід справедливий також, якщо конденсована фаза є електронно-дірковою рідиною. Для цього при спінодальному підході в рівнянні для екситонної густини (14) замість $n$ треба мати на увазі густину електронно-діркових пар. У моделі зародження-росту метод, використаний для дослідження конденсації екситонів в [20-24], подібний до методів, використаних у [45-47] при дослідженні електронно-діркових крапель в германії та кремнії. Проте на відміну від робіт [45-47], нами враховано кореляцію в положенні крапель, що дозволяє описувати різноманітні структури, взаємне положення крапель, їхню концентрацію та інші властивості, що спостерігаються у квантових ямах на базі AlGaAs.

1. T. Fukuzava, E.E. Mendez, and J.M. Hong, Phys. Rev. Lett. 64, 30066 (1990).

2. A.V. Larionov, V.B. Timofeev, J. Hvam, and K. Soerensen, JETP Lett. 71, 117 (2000).

3. А.А. Дремин, А.В. Ларионов, В.Б. Тимофеев, ФТТ 46, 168 (2004).

4. В.Б. Тимофеев, УФН 175, 315 (2005).

5. L.V. Butov, A.C. Gossard, and D.S. Chemla, Nature 418, 751 (2002).

6. B.D. Snoke, S. Denev, Y.Liu et al., Nature 418, 754 (2002).

7. L.V. Butov, Solid State Commun. 127, 89, (2003).

8. D. Snoke, Y. Liu, L. Pfeifer, and K. West, Solid State Commun. 127, 187 (2003).

9. A.V. Gorbunov and V.B. Timofeev, JETP Lett. 83, 146 (2006); V.B. Timofeev, Usp. Fiz. Nauk 176, 651 (2006).

10. V.V. Solov'ev, I.V. Kukushkin, V. Smet et al., JETP Lett. 83, 533 (2006).

11. A.V. Gorbunov and V.B. Timofeev, JETP Lett. 84, 329 (2006).

12. В.Б. Тимофеев, А.В. Горбунов, Д.А. Демин, ФНТ 37, 229 (2011).

13. M. Remeika, J.C. Graves, A.T. Hammark et al., Phys. Rev. Lett. 102, 186803 (2009).

14. L.S. Levitov, B.D. Simons, and L.V. Butov, Phys. Rev. Lett. 94, 176404 (2005).

15. A.V. Paraskevov and T.V. Khabarova, Phys. Lett. A 368 151 (2007).

16. R.B. Saptsov, JETP Lett. 86687 (2008).

17. C.S. Liu, H.G. Luo, and W.C. Wu, J. Phys.: Condens. Matter 18, 9659 (2006).

18. V.S. Babichenko, arXiv/cond-mat: 0706.0994 (2007).

19. V.K. Mukhomorov, Fiz. Tverd. Tela 52, 225 (2010).

20. V.I. Sugakov, Ukr. Fiz. Zhurn. 49, 1117 (2004); Solid State Commun. 134, 63 (2005).

21. V.I. Sugakov, Fiz. Tverd. Tela 48, 1868 (2006); Physics of the Solid State 48, 1984 (2006); Fiz. Nizk. Temper. 32, 1449 (2006).

22. V.I. Sugakov, Phys. Rev. B 76, 115303 (2007).

23. A.A. Chernyuk and V.I. Sugakov, Phys. Rev. B 74, 085303, (2006). 
24. V.I. Sugakov and A.A. Chernyuk, JETP Lett. 85, 570 (2007).

25. M.Y.I. Tan, N.D. Drummord, and I. Needs, Phys. Rev. B 71, 033303 (2005).

26. Ch. Schindler and R. Zimmermann, Phys. Rev. B 78, 045313 (2008).

27. A.D. Meyertholen, and M.M. Folger, Phys. Rev. B 78, 235307 (2008).

28. A.A. Chernyuk and V.I. Sugakov, Solid State Communication 149, 2185 (2009).

29. Yu.E. Lozovik and O.L. Berman, JETP Lett. 64, 573 (1996).

30. В.И. Сугаков, ФТТ 28, 2441 (1986); V.I. Sugakov, Lectures in Synergetics (World Scientific, Singapore, 1998).

31. Sen Yang, A.V. Mintsev, A.T. Hammack, L.V. Butov, Phys. Rev. B 75, 033311 (2007)

32. А.В. Горбунов, В.Б. Тимофеев, Письма в ЖЭТФ 84, 390 (2006).

33. Sen Yang, A.T. Hammack, M.M. Fogler, and L.V. Butov, Phys. Rev. Lett. 97, 187402 (2006).

34. V.I. Sugakov, Solid State Commun. 106, 705 (1998).

35. A. Ishikawa, T. Ogawa, and V. Sugakov, Phys. Rev. B 64, 144301 (2001).

36. A. Ishikawa and T. Ogawa, Phys. Rev. E 65, 026131 (2002).

37. B. Link and G. Bayn, Phys. Rev. Lett. 69, 2959 (1992).

38. M.R. Swift, E. Orlandini, W.R. Osborn, and J.M. Yeomans, Phys. Rev. E 54, 5041 (1996).

39. V.I. Sugakov, Phase transitions 75, 9532002.

40. V.I. Sugakov, J. Phys.: Condens. Matter 21, 275803 (2009).

41. J. Kasprzak, M. Richard, S. Kundermann, A. Baas, P. Jeambrun, J.M.J. Keeling, F.M. Marchetti, M.H. Szymanska, R. Andre, J.L. Staehli, V. Savona, P.B. Littlwood, B. Deveaud, and Le Si Dang, Nature 443, 409 (2006).

42. L.V. Butov, A. Imagoglu, A.V. Mintsev, K.L. Campman, and A.C. Gossard, Phys. Rev. B 59, 1625 (1999); L.V. Butov, A.L. Ivanov, A. Imagoglu, R.B. Littlewood, A.A. Shashkin, V.T. Dolgopolov, K.L. Campman, and A.C. Gossard, Phys. Rev. Lett. 86, 5608 (2005).

43. V.S. Kerner, Vyacheslav V. Osipov, Soviet Physics Uspekhi 33, 679 (1990).

44. I.M. Lifshiz and V.V. Slyozov, J. Phys. Chem. Solids 19, 35 (1961).

45. R.N. Silver, Phys. Rev. B 11, 1569 (1975).

46. R.M. Westervelt, Phys. Status Solidi B 74, 727 (1976).
47. V.S. Bagaev, N.V. Zamkovets, L.V. Keldysh, N.N. Sybel'din, and V.A. Tsvetkov, Zh. Eksp. Teor. Fiz. 70, 1501 (1976) [Sov. Phys. JETP 43, 783 (1976)].

Одержано 29.07.11

КОНДЕНСАЦИЯ ЭКСИТОНОВ В КВАНТОВЫХ ЯМАХ. САМООРГАНИЗАЦИЯ ПРОТИВ БОЗЕ-КОНДЕНСАЦИИ

\section{В.И. Сугаков}

$\mathrm{P}$ е $з$ ю м е

Проведен анализ интерпретации экспериментальных данных по спектрам излучения экситонов в двойных квантовых ямах. Особенности пространственного распределения излучения, его поведение в зависимости от температуры, интенсивности накачки, и внешнего потенциала объясняются с точки зрения существования экситонной конденсированной фазы, обусловленной взаимодействием между экситонами, а не бозе-эйнштейновской конденсацией экситонов. Структура пространственного распределения экситонной плотности конденсированной фазы зависит от времени жизни экситонов и является следствием процессов самоорганизации в неравновесных системах. Исследовано взаимное распределение возбуждений по ловушкам и состояниям свободных экситонов и его влияние на спектры излучения. Получено уравнение гидродинамики экситонов, учитывающее взаимодействие между экситонами. Показано существование солитоноподобных состояний (автосолитонов) за границей области спинодального распада.

EXCITON CONDENSATION IN QUANTUM WELLS. SELF-ORGANIZATION AGAINST BOSE-CONDENSATION

\section{V.I. Sugakov}

Institute for Nuclear Research, Nat. Acad. of Sci. of Ukraine (47, Prosp. Nauky, Kyiv 03680, Ukraine)

$\mathrm{S}$ u m m a r y

The analysis of interpretations of the experimental data on the emission spectra of excitons in double quantum wells is carried out. Features of both the spatial distribution of the emission and its behavior depending on the temperature and the pumping intensity are explained by the appearance of the condensed phase of excitons caused by their interaction. The explanation does not involve the Bose-Einstein condensation of excitons. The spatial distribution of the exciton density in the condensed phase depends on the exciton lifetime and is a consequence of self-organization processes in the non-equilibrium system. The distribution of excitons over trapped and free states and its influence on the emission spectra are investigated. The hydrodynamic equations for interacting excitons are obtained. The existence of soliton-like states (autosolitons) outside of the spinodal decomposition region is shown. 